\title{
THE CONCEPT OF MODERN DUTCH COLONIAL ARCHITECTURE TO THE DEVELOPMENT OF JAVANESE ARCHITECTURE
}

\author{
ARDIYANTO, Antonius ${ }^{1 *}$; DJUNAEDI, Achmad ${ }^{1}$; IKAPUTRA,Suryabrata'; DJADMIKA, Adi ${ }^{1}$ \\ ${ }^{1}$ Gadjah Mada University, Faculty of Engineering, Architecture Department \\ Jalan Grafika No. 2 Campus UGM, Yogyakarta 55581, INDONESIA \\ * Corresponding author: ardi_diet@yahoo.com
}

\begin{abstract}
Modern architecture colonial present in the early 20th century, when several Dutch graduate architects had begun profession in the Dutch East Indies. The architects of had understood that the development of modern architecture in the East Indies must include the local environment and climate aspects of traditional architecture that has existed in the Dutch East Indies. In this case, two famous architects, the Thomas Karsten and Henri Maclaine Pont, became a pioneers in this movement. The concept of the modern architecture development base on the Java architecture has been carried out by Thomas Karsten with several his works such as office buildings, hospitals, markets, and schools. The potential of traditional Javanese architecture in terms of shape, material and solving the problems of the tropical climate conditions, aims to achieve comfort in the building the use of potencies has been used as a concept for the development of modern Dutch colonial architecture.
\end{abstract}

Keywords: Javanese architecture; modern colonial architecture.

\section{INTRODUCTION}

In Indonesia, the development of the mixture of traditional architecture into modern architecture persists to this day. Government offices in various provinces, cities and districts in Indonesia such as in Central Java, Bali, Sumatra, Borneo and others have developed their local architecture as part of the development of their modern architecture such as offices, campuses, hospitals, markets and other, which its shapes influenced by indigeneous architecture. Buildings with unique traditional architecture are easily found, such as in traditional houses of Minangkabau in Sumatra, Pendapa Joglo Houses of Java, Tongkonan Houses of Toraja, traditional Balinese houses, and other traditional houses in various parts of Indonesia. The traditional buildings has been constructed as a cultural product which is passed from generation to generation, which can be seen from the building shape, layout, building structures as well as building materials using local materials. In addition the building is designed to adjust to the humid tropical climate conditions in Indonesia.

The development of traditional architecture on modern architecture in Indonesia has actually started in the Dutch colonial period, particularly in the early 20th century (years 1910 to 1940 's) when many Dutch architects worked and practiced in Indonesia. Some architectural trends were growing in Indonesia, which all of them were based on the modern architecture developed in America and Europe.
At that time several professional architects began to express their idea to apply traditional architectural elements in the design of modern buildings of colonial Dutch architecture. The pioneer of this trend were: Henri Maclaine Pont and the well-known architect and city planner Thomas Karsten. These two- architects can be considered as a pioneer who developed the architectural character of "Indische" (Akihari, 1988). Several buildings were already built by these architects, i.e.: office buildings, schools, hospitals, stations, museums, markets, theaters and homes.Those design are applied the mixed architectures, traditional and modern architecture.

The description of the architecture developed in the early 20th century as depicted by Handinoto, 1996, figured out that the form of Dutch colonial architecture in Indonesia after the 1900's had a specific form. The shape was the result of compromising between modern architecture that flourished in the Netherlands and a humid tropical climate conditions in Indonesia. There were also several Dutch colonial buildings that took the local traditional elements to its architecture. In summary, the Dutch colonial architecture applied in Indonesia showed a different form of those in the Netherland.

This article is organized as a literature review on the development of traditional Javanese architecture in modern Dutch colonial architecture. Case study consists of 2 buildings planed by famous Dutch architect Thomas Karsten is a theater building which 
includes the Office of the People Sobokarti and PT. KAI DAOP IV Semarang, which is still functioning and preserved.

\section{RESEARCH METHOD}

This article is written based on the literature research on the development of Javanese architecture on modern Dutch colonial architecture. The method used in the research is the literature review research method. The literature review is a complex process that can be defined as an interpretation of a selection of published and/or unpublished documents available from various sources on a specific topic that optimally involves summarization, analysis, evaluation, and synthesis of the documents (Onwuegbuzie et al., 2012, p.2).

Based on Onwuegbuzie et al. (2012), the analysis method was used in the research is a withinstudy literature analysis. The anlysis involves analyzing the contents of a specific work. In its most rigorous and comprehensive form, a within-study literature analysis does not merely involve analyzing the findings of a study or the major premise used in a non-empirical work. Rather, optimally, it involves analyzing every component of the work, including the title, literature review section, conceptual framework/ theoretical framework, procedures used, results section, and discussion section.

The research used data from several kinds of resouces, such as research articles, opinion articles, essays, article reviews, dissertations, books, Internet websites, video, encyclopedias, government documents, and popular magazines. The data, then, analysed by narrative analysis method, by considering the potential of stories to give meaning to research findings, and treating data as stories, enabling reviewers to reduce data to a summary.

\section{JAVANESE TRADITIONAL ARCHITECTURE}

Javanese traditional architecture is one of the Javanese cultural products. Traditional Javanese house, as a product of Javanese culture, has multi functions, not only privately owned, but also a social function as part of Javanese culture (Santosa, 2000). Javanese house riches with symbolic meaning, sociocultural values as well as architectural value, together with a unique structure that is adapted to the environmental conditions, culture and climate. In essence, Javanese traditional architecture, particularly in Central Java, based on a form of residential house. According to Ismunandar (2003), there are some
Javanese houses existed in Indonesia. Those are the following:

1. Joglo House

2. Limasan House

3. "Kampung"/Village House

4. Houses with Mosque shape and "Tajug" or "Tarub".

5. "Panggang Pe" House.

The design concept of the Javanese architecture is based on Java manuscript, known as "Kawruh Kalang" (Muqoffa, 2011).'Kawruh Kalang" itself is a Javanese building design guidance. From 5 types of the Javanese houses, Joglo is the most often discussed as a representation of the Javanese architecture. Joglo house is usually owned by rich people or is owned by the highly respected people and has a high social status in the Javanese community. Joglo house is highly cost and needs more materials, therefore only rich people who can effort to built Joglo. The shape of Joglo house is usually square and has four main columns/pillars. The arrangement of the main spaces in Joglo house are divided into three parts, namely meeting hall or "pendapa", living room or space that is used to perform a puppet show called "pringgitan", and a back part of the house called "dalem" or "omah jero" which functioned as a family room. "Dalem" has three kinds of Sentong (rooms); it is Sentong "kiwa" (left part), Sentong tengah/middle part (petanen) and Sentong "tengen"/right part. (Ismunandar, 2003), see figure 1.

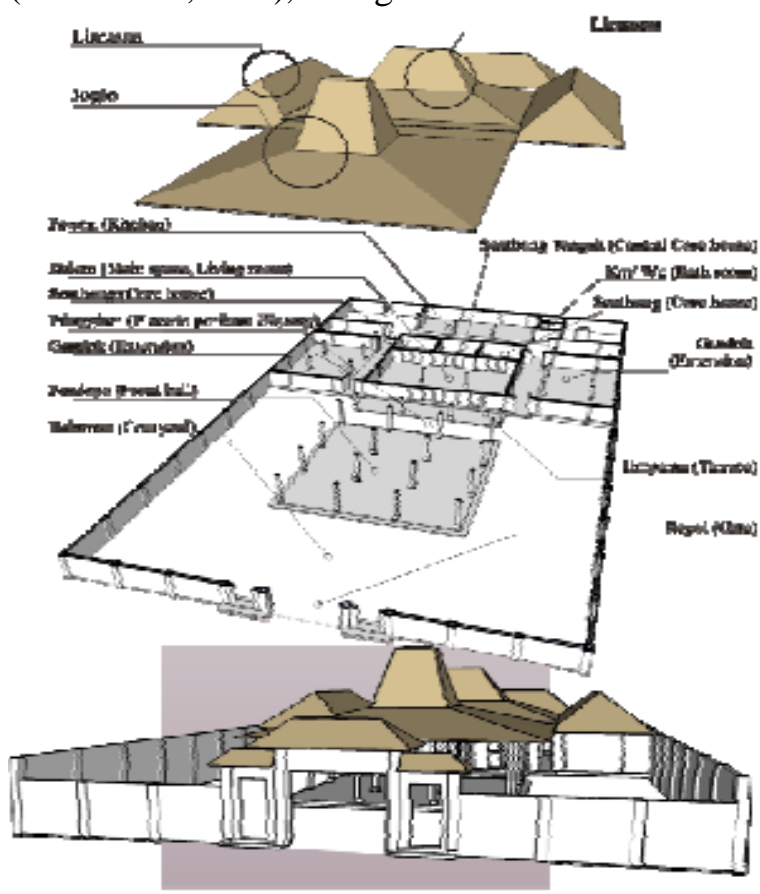

Source: Maqoffa, M, 2011

Figure 1. Javanese Joglo house spatial 
The composition of those spaces are strongly influenced by the Javanese mythology and cosmology. This means that traditional Javanese house is not only as a shelter (practical function), but also interpreted as an embodiment of the ideals and philosophy of life (symbolic function). (Djono, Utomo, Subiyantoro, 2012).

The traditional Javanese house has several symmetrical rooms and there is a hierarchy of space inside. From the outside there is a common public space, and the space becomes private when going deeper to go inside the house. The outside, so-called terrace is an open space without roof. The terrace is also a public space used as a transition area from the outside into the house. The next room, the pendapa, still serves as a public space. This room is functioned by the host to receive guests. Pendapa has a squareshaped space and has four main columns (pillars) called "saka guru" located in the middle of the hall. This room does not have borders on all four sides. This symbolizes openness of the owner against anyone who comes. Pendapa describes the harmony of the Java community lifestyle, see figure 2.

Form of one of the rooms in the house the Javanese tradition shows a deep philosophical concept of the meaning of space, with the presence of the "pendapa" as the embodiment of the concept of harmony in the Java community lifestyle. Pendapa not just a place, but it has a deeper philosophical meaning, namely as a place to actualize a form harmony between residents and the surrounding community. Pendapa is a social space application in the Java community. (Djono, Utomo, Subiyantoro, 2012).

Pringgitan is a transitional space between public and private space that located between the "pendapa" and "dalem ageng". Pringgitan also used as a place to perform puppet show when there is circumcision ceremony, ruwatan, marriage and so on. The room



Source: www.infobisnisproperti.com

Figure 2. Pendapa called a "dalem ageng" consider as a private room, which one of its function serves as a gathering space the whole family. The shape of this room/space is square, covered with a wall on each side. Inside the "dalem ageng" there are three rooms with similar in size "senthong". "Senthong kiwa" and "senthong tengen" on either side are used for sleeping for the male and female family members, while the "senthong tengah" which located in the centre, between "senthong kiwa" and "senthong tengen" is regarded as a sacred place. "Senthong tengah" or "krobongan" is believed to be a place of worship to the Dewi Sri, the Goddess of Fertility and the happiness. This place is the most private area/private in the Javanese tradition. (Djono, Utomo, Subiyantoro, 2012:274).

\section{INDO - EUROPEAN ARCHITECTURE}

Colonization of Indonesia by the Dutch lasted about 350 years. In the Dutch colonial many colonial buildings with various architectural typologies and evolving appropriate time were built. At the beginning of the Dutch colonialization, during the colonial era of the VOC in 17th century until 18th century, Indische architecture which copied the aristrokratic style of the upper society in Europe, has flourished. This architecture had been applied mostly in the VOC officials's house; they live in rural outskirts of the city of Batavia (now Jakarta). Houses are also known as a landhuizen, a house surrounded by extensive gardens. (Handinoto, 2010:47). Indische architecture had evolved until the 19th century. Indische architecture was experiencing growth in the early 19th century, together with the arrival of the Governor -General H.W. Daendels (1808-1811), a French army of Louis Napoleon brought the influence of architecture which is known as the Empire Style. This architecture developed in France and influenced by neoclassical architecture. In the Dutch East Indies, this style of architecture became known as Indiche Empire Style, which adjusted to the climate, technology and local materials. (Handinoto, 2010:51).

In its development after many Dutch architects came to the Netherlands East Indies (Indonesia) in the early 20th century, along with the development of industry, building technology, including building materials in the Netherlands East Indies, then developed a modern architecture in the Dutch East Indies.

Around 1920, in the Dutch East Indies emerged Indo Europeesche Stijl (Indo European architecture style) which is a mixture of modern European architecture and local architecture. The style was pioneered by Maclaine Pont and Thomas Karsten. 
This architectural style was disputed by Pont $\&$ Wolf Schoemaker (professor of architecture at the ITB). (Handinoto, 1996).

Examples of buildings that can be classified in this style including building Technisch Hogeschool/ ITB-Bandung (Maclaine Pont 1919), Theatre Sobokarti-Semarang (Thomas Karsten, 1930), Sonobudoyo-Yogyakarta (Thomas Karsten, 1930), the Pohsarang Church - Kediri (Macaline Pont, 1936) and many more. (Yulianto, 1993). At that time, the Indo European architectural style was classified as one of the efforts to find the identity of the Dutch East Indies architecture so called "Indo European Style" (indo European style architecture), and it was reflected on the facade of the building which had a blend of local architecture and modern architecture with adaptation to climate, materials and technology. Functionalism in the modern architecture has been combined by the Dutch colonial architect with the formation of local architecture and adapted to the humid tropical climate conditions. One of the example was to apply the traditional Javanese architecture to the modern Dutch colonial buildings, so in consequences, the expression of the building was different when compared to modern building architectures in the Netherlands or Europe in general.

\section{THE DEVELOPMENT OF JAVANESE ARCHITECTURE IN MODERN ARCHITECTURE COLONIAL}

Architecture is the materialization of culture therefore, the architecture is a reflection of culture. Material culture in the form of architecture is a silent witness of the history which experienced by the nation or community in which the building existed. (Handinoto, 2010:55)

Modern architecture in the Dutch colonial period is influenced by culture, technology and local conditions. The effort to apply the local elements into modern architecture was echoed primarily by Mclaine Pont and Thomas Karsten, even though they had different approaches. Mclaine Pont tends to combine various forms of traditional architecture in Indonesia and trying to innovate with modern structures form, while Thomas Karsten tends to develop traditional Javanese architecture. (Ardiyanto, 2009). This is because in certain period (years 1917-1920) Thomas Karsten with the command of the Javanese King Mangkunegoro VII was asked to renovate, extend and modificate Mangkunegaran Palace. The experience of renovating Joglo in Kraton Mangkunegoro (NAS, 2010), might inspired Karsten to design others buildings. In his design, Thomas Karsten tried to implement Javanese Joglo structure. Some architec- ture products designed by Karsten are: museums, theaters, offices and schools, multipurpose room pavilion which used the concept of joglo form (pendapa).

There are several architectural product of Thomas Karsten which integrating traditional Javanese architecture concept and modern architecture, the example are People's Theatre Building Sobokarti and PT. Indonesian Railways DAOP IV (formerly known as Zustermaskapijn) in Semarang.

Sobokarti theater building in Semarang is a building which was built to support the traditional javanese art especially Javanese dance "karawitan" and shadow puppet. This theater has adapted the form of the Javanese hall building "Joglo" (Groll, 2002; Kusno, 2000). Quadrangular theater room, the main hall of the building, has structure like a Joglo structure, with four main pillars "saka guru" supporting the building and a modified three-layered roof. The main room on the traditional Javanese architecture had been transformed into a theater as the European concept. The main room is equipped with a stage and grand stand, which never be found in the pendapa, see figure 3 .

The Form of "tumpang sari" on the pillar or "saka guru" had been modified into simpler form to accommodate the functional requirements, the stage and tribun had also been performed which previously unknown in the joglo system. Karsten was developing that concept especially designing a theater, see figure 4.

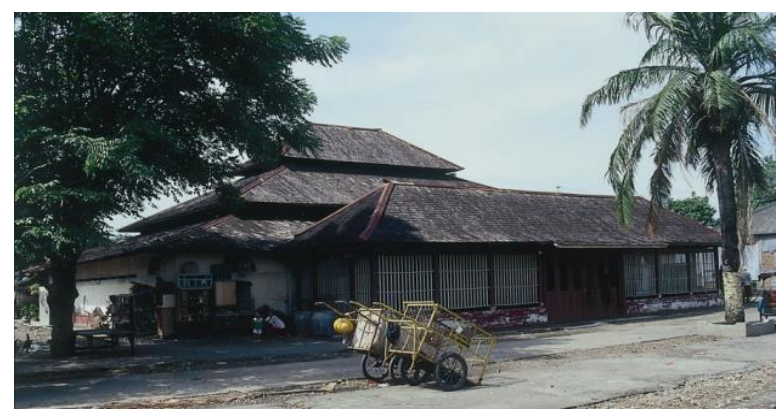

Source: http://seputarsemaran.com/gedung-kesenian-sobokarti)

Figure 3. Sobokarti People Theater

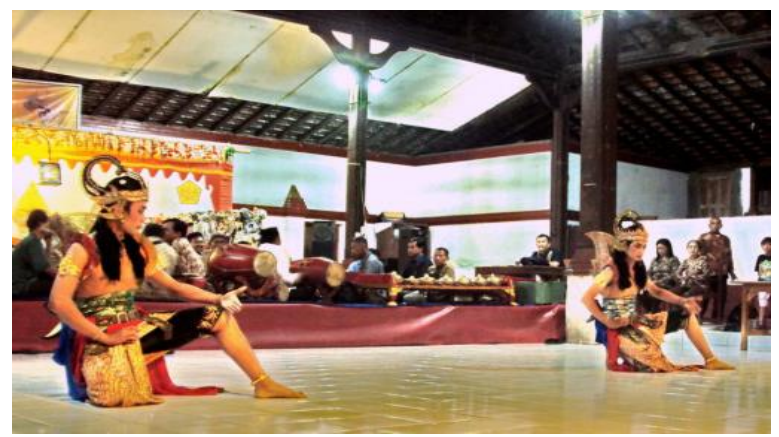

Figure 4. Interior Sobokarti 
The building which looks like pringgitan used as a placed for reception before entering the theater. Pringgitan space is also used as a dance rehearsal or other activities.

Inside, there is a wide space, with rafters, battens and tiles are exposed look of natural wood materials and ventilation arrangement between the rooftop for natural ventilation. Lower circumferential wall was built with openings for lighting and air flow. Ornamentations of the surrounding walls are Hindu fences.

Until now Sobokarti theater building still functioned as a building for the preservation of Javanese culture through training and Javanese dance performances, shadow puppet show, kerawitan exercise or other activities undertaken by the community or the Javanese art conservationist. On several anniversaries related to the construction of the Sobokarti building, there were some performances which actualized the Javanese culture. One of the celebration is the commemoration of 81 years Sobokarti 1931 to 2012.

The other works of Thomas Karsten which applying traditional Javanese architecture into modern architecture is PT. KAI Daop IV (Zustermaatschappijen). This building was built in 1930 as a modern office building with concrete structures. In designing this office, Thomas Karsten using modules of $2.42 \mathrm{~m}$ is equal to the size of 12 tiles, at a distance of portico columns surrounding the building. The columns are combined with the shape of the roof that was getting increasingly rising to the middle, most likely inspired by Javanese Joglo house. (Yulianto, 1993)

In addition, there is also a character of Joglo house in levels or differences in the value space. The first is a portico or alley surrounding the building, serves as a transition from outside to inside. The second is an office space, a library on the left wing, meeting rooms, secretarial and reception area at the front, and the head of the office on the right wing as a semi-public space. The third part is a space that is private, located in the middle, an archive room and space for employees with room size $22 \times 32 \mathrm{~m}$, height of $10.44 \mathrm{~m}$, with identical row of columns remind to the form of joglo (Yulianto, 1993:42), see figure 5.

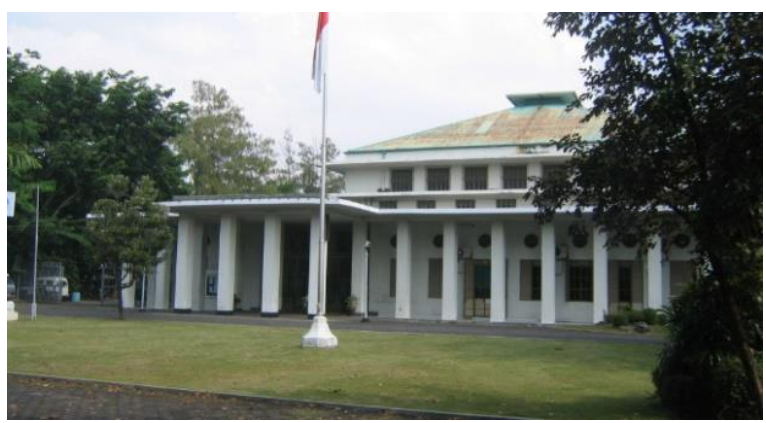

Figure 5. PT.KAI DAOP IV office Semarang
Living room is a space for activities that are open plan, which is surrounding by column and width of the window at the top of the wall, which is located on the roof of a side room, which serves to lighting and ventilation. In each office space is completed with doors and wide windows as well as wide ventilation. Although the rooms are arranged in depth, but because of having a high ceiling (5.44 and $10.44 \mathrm{~m}$ of space at the edge of the living room) with large ventilation holes through doors, windows and special ventilation holes, the air flow in the room is good enough and the air quite fresh. (Yulianto, 1993), see figure 6 .

Based on the above discussion, there is a difference between the two buildings designed by Karsten. In the case of the theater of Sobokarti, the Javanese traditional atmosphere is still strong. As a building which serves to accommodate the activities of Javanese art, form and function of the building still shows the proximity of the Javanese building, which still functioned as a social space or public space similar like the function of Joglo house. The function of the building to accommodate Javanese traditional art activities such as Javanese dance, shadow puppet show, or other Javanese development art, is still very relevant in the mission of developing a culture of Java. The dominant building materials using local natural materials such as wood for columns, beams and roof trusses and exposed wood shingle tiles seem friendly and lightweight. In term of the scale of the building, the Sobokarti theatre is classified into moderate scale that allows the closer interaction between users. This is because the proportion of building is not much different from the Javanese Joglo building scale, only wider in space.

Unlike the Sobokarti theater, office buildings PT. KAI DAOP IV is a modern office building with concrete and steel technology. The structure of the building is a concrete structure with a steel roof truss.

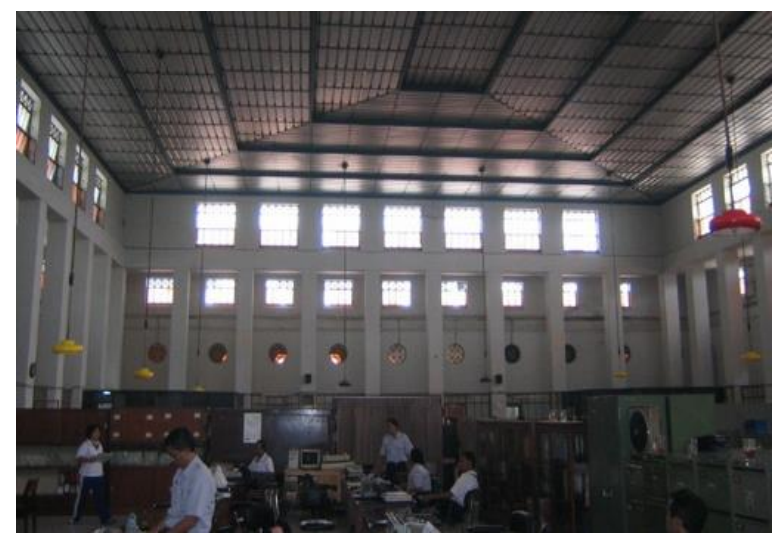

Figure 6. Interior PT. KAI DAOP IV office 
Row of columns in the hallway outside of the building (portico) gives the impression of solid and heavy. The roof of the building is consisted of a threelayered roof. Two bottom composition comprising slab concrete roof and the roof peak which is corrugated iron roofs. Judging from the scale of the building, then the building considered as a huge office building with a very large living room size of $22 \mathrm{~m} \mathrm{x}$ $32 \mathrm{~m}$ high ceiling with 10:44 m, larger than Joglo as the Java residential building. In this case the inspiration of traditional Javanese architectural forms is used for the preparation of the forms of modern architecture office buildings of PT. KAI Daop IV Semarang.

Judging from the function of the building, the PT KAI Daop IV Semarang is different from Javanese Joglo building, but if it is observed from outside the building as well as from surrounding location, placing a row of outside columns of the building and the form of the roof reflected the breath of the Javanese traditional architecture in the modern office building.

\section{CONCLUSION}

From these discussions it can be concluded that traditional Javanese architecture had been developed by architects in the colonial period into a modern building. The implementation of the mixed architecture in the building is sometime created with an adjacent function or completely different from the function of traditional building. The concept of Javanese traditional architecture could also be adapted to the function of the modern buildings in the form of spatial development, the shape and the scale of the building.

Furthermore, the element of the roof became the dominant architectural element for the development of forms of traditional architecture on modern architecture colonial Java, because through the roof the building can be easily recognized and adapted to the shape of the buildings in the surrounding neighborhood.

In the case of Sobokarti theater and the office of PT. KAI DAOP IV in Semarang, it can be seen that there are different approaches in the development of the Java architecture. Building structure and architectural design of Sobokarti theatre are close to traditional Javanese architecture, in term of the performance, form, structure, building material and layout. While, at the office of PT. KAI DAOP IV, the performance is tends to be dominant as a modern architecture especially in the structure and building materials. But, in terms of form expression, it has strived to Javanese architecture. Until now, the existence of Sobokarti theater and PT. KAI DAOP IV office building are still functioning well and dedicated into preservation buildings. The existence of those two buildings could be reffered for young generation as the integration of Javanese traditional architecture building and modern architecture.

\section{REFERENCES}

Akihari, H. (1990). Architecture \& Stedebouw in Indonesie 1870-1970, De Walburg Pers, Zutphen.

Ardiyanto, A. (2009). Thomas Karsten dan Inovasi Pengembangan Arsitektur Tradisional Jawa, Proseding Seminar Nasional, Penerbit Arsitektur Unmer Malang, II.251-II.260

Djono, T.P.U. \& Subiyantoro, S. (2012). Nilai Kearifan Lokal Rumah Tradisional Jawa, Humaniora, 24(3), p. 269-278

Hadinoto \& Soehargo, P. H. (1996). Perkembangan Kota \& Arsitektur Kolonial Belanda di Malang, Andi Offset, Yogyakarta.

Handinoto, (2010). Arsitektur dan Kota-kota di Jawa Pada Masa Kolonial, Penerbit Graha Ilmu. Yogyakarta

Kusno, A. (2000). Behind the Postcolonial: Architecture, Urban Space and Political Cultures in Indonesia, Routledge, London and New York.

Nas, P.J.M. (2000). Masa Lalu Dalam Masa Kini Arsitektur di Indonesia, Penerbit Gramedia Pusaka Utama.

Muqoffa, M. (2011). Sustainable Design and Construction in the Javanesse Architecture. Case: Kampung Laweyan Surakarta, Proceedings International Conference: Local Wisdom in Global Era, Duta Wacana Christian University, Yogyakarta. A.159-A.167

Sumalyo, Y. (1993). Arsitektur Kolonial Belanda di Indonesia, Gajah Mada University Press.

Onwuegbuzie, A.J., Leech, N.L. \& Collins, K.M.T. (2012). Qualitative Analysis Techniques for the Review of the Literature. The Qualitative Report, 17(56), p. 1-28 